\title{
Incidence of milk alkali syndrome in the Women's Health Initiative clinical trial and cohort study
}

\author{
S. Neupane
}

Received: 4 March 2013 / Accepted: 10 July 2013 /Published online: 3 August 2013

(C) International Osteoporosis Foundation and National Osteoporosis Foundation 2013

\section{Dear Editor,}

Milk alkali syndrome is a condition which has been considered to be on the rise with the use of calcium carbonate for osteoporosis prevention globally. It is considered to be the third most common cause of hypercalcemia in non-end-stage renal disease inpatients $[1,2]$. There have been many reports of milk alkali syndrome from calcium carbonate intake ranging from 1 to $9 \mathrm{~g}$ of elemental calcium per day. However, most of these patients had other comorbidities like chronic kidney disease or use of diuretics, which can predispose them to the syndrome [1]. In the article "Health risks and benefits from calcium and vitamin D supplementation: Women's Health Initiative clinical trial and cohort study" [3], Dr. Prentice and colleagues addressed the health benefits and risks seen with calcium and vitamin D supplementation, but they have not mentioned anything about the occurrence or absence of milk alkali syndrome in this large sample. The study included a significant number of subjects who were more than 70 years of age and significant number of subjects who were taking more than $1,200 \mathrm{mg} /$ day of calcium in the form of calcium carbonate along with vitamin D supplementation. Increasing reports of milk alkali syndrome with calcium carbonate use raises the question if just calcium citrate should be used for osteoporosis prevention despite the higher cost of administering calcium citrate compared to administering calcium carbonate. It will help clinicians make a choice regarding the type of calcium supplement if the authors could clarify if there was any occurrence of milk alkali syndrome in the large sample from the community that was followed up for 7 years. Additional information about the prevalence of chronic kidney disease, use of diuretics, and use of proton pump inhibitors in those patients will also help in the decision making.

\section{References}

1. Picolos MK, Lavis VR, Orlander PR (2005) Milk alkali syndrome is a major cause of hypercalcemia among non-end-stage renal disease (non-ESRD) inpatients. Clin Endocrinol (Oxf) 63(5):566-576

2. Felsenfeld AJ, Levine BS (2006) Milk alkali syndrome and the dynamics of calcium homeostasis. CJASN 1(4):641-654

3. Prentice RL, Pettinger MB, Jackson RD, Wactawski-Wende J, LaCroix JA, Anderson GL, Chlebowski RT, Manson E, Van Horn L, Vitolins MJ, Datta M, LeBlanc ES, Cauley JA, Rossouw JE (2013) Health risks and benefits from calcium and vitamin D supplementation: Women's Health Initiative clinical trial and cohort study. Osteoporos Int 24(2):567-580
A reply to this letter can be found at doi 10.1007/00198-013-2461-z.

S. Neupane $(\bowtie)$

Department of Medicine, Suny Upstate Medical University,

Syracuse, NY, USA

e-mail: neupanes@upstate.edu 